\title{
UBIQUE - THE GUNNERS OF SOUTH AFRICA
}

\section{Col. L.A. Crook, SM, JCD*}

The story of the Gunners of South Africa perhaps began with the arrival in Table Bay in April, 1652 of Jan van Rieceeck, for he surely had with him some trained gunners to supervise, if not man, the cannon of the Fort de Goede Hoop. Since that time hundreds, if not thousands, of men representing the Dutch East India Company and the Royal Artillery have in turn been stationed in this country to man the defences at the Cape and elsewhere, not to mention the countless numbers who have served in volunteer units and in units of the various Brigades that have gone to make up the South African Artillery Corps as we know it today.

The first artillery unit actually raised in this country would appear to be the so-called Malay Artillery, formed at the Cape in November, 1804, with a strength of between three and four hundred, including an Infantry component, and 16 guns. They were drilled on both field and fort guns and were apparently well thought of. Ten afterwards lost their lives at the Battle of Blaauwberg.

It was mid-1800's, however, that saw the real birth of Artillery in South Africa and many units were formed about this time, particularly in the Cape which had been experiencing a series of Native Wars on the Eastern Frontier.
The first to appear was the Simon's Town Artillery on 11 July, 1857, with an authorised strength of one Company. Its strength in September of that year was 19, with a Lt. H.M. Anderson as Commanding Officer. Their numbers in fact never appear to have exceeded one officer and 19 men, but they were obviously a keen group of Gunners for old records reveal their involvement in Reviews, including that at Stellenbosch in October, 1857, field days and at gun drill on the Simon's Town defences. They were also responsible for firing a Royal salute for the visit of Prince Alfred to Simon's Town on 24 July, 1860 and another salute in September. They were, however, disbanded in 1861, for their duties were taken over by the PAOCVA whose Commanding Officer had also taken under his wing responsibility for the Simon's Town men.

About the same time as the above unit was formed the Stellenbosch Artillery came into being, and although not much is known about them it is recorded that twenty four men under Sgt. Lindsay were present at the review at Stellenbosch on 7 October, 1857 and that they fired a salute. They are also noted in June 1857 as having "very small guns", but no further mention is made of them after March, 1862.

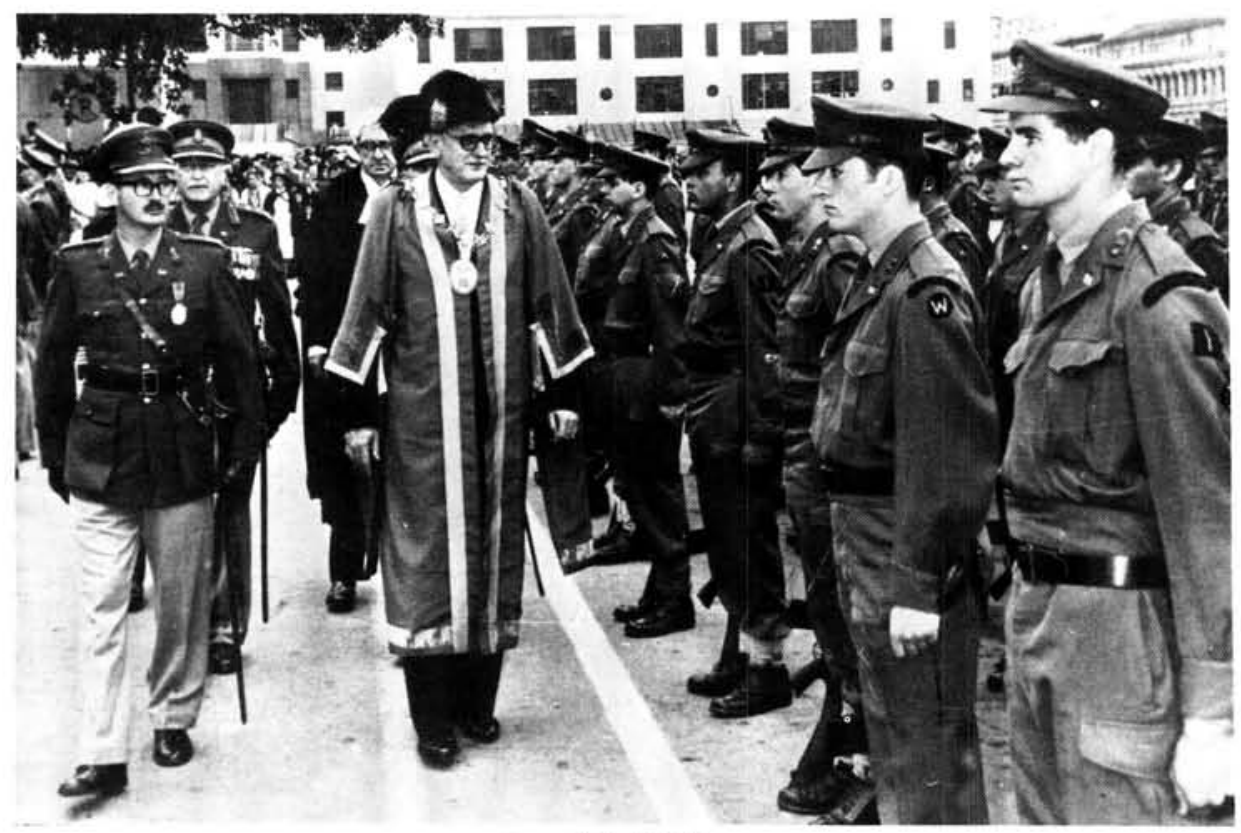

Cape Field Artillery. 
The present Cape Field Artillery was raised as the Cape Town Volunteer Artillery on 26 August, 1857 with an initial strength of 60 under command of Chevalier Alfredo Du Prat, a Portuguese gentleman who was a member of the Mixed Slavery Commission, and also Portuguese Consul at the Cape, as well as being Consul for France, Belgium and Italy. Although equipped with brass 6-pounder field guns and wearing field artillery dress with busby and carrying swords, the men also trained on the heavy coastal ordnance of the Cape defences. Thus for many years the Cape Town gunners filled a dual role as field and coast artillerymen, finally withdrawing from drill on the heavier ordnance in 1897 in which year the coastal batteries were taken over by the Coast Garrison Artillery and the Prince Alfred's Own Cape Artillery as they were by then known, were converted from field to that of a horse artillery role with 15-pounder guns.

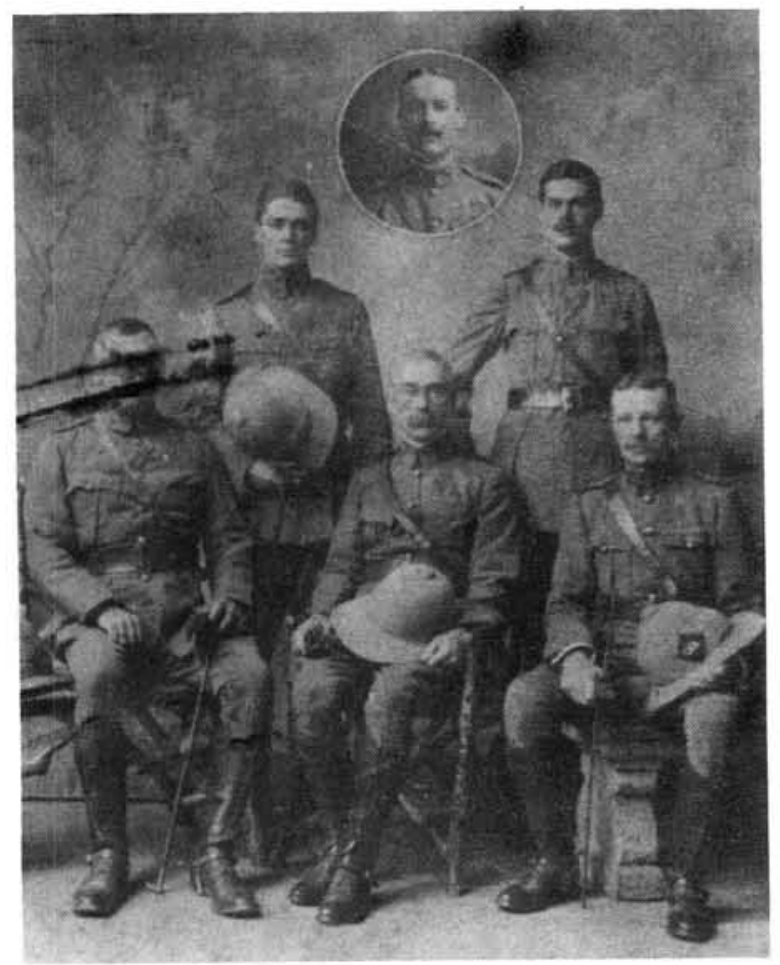

Prince Alfred's own Cape Artillery.

The Cape Town Volunteers were followed by the George Town Mounted Burger Artillery whom the Cape Argus of 21 June, 1858 noted were on parade on the Queen's Birthday, having that day fired a 21 gun salute. Sadly the Cape Monitor of 1st June, 1859 records that at a Ball in May one man was present dressed in the uniform of the George Artillery Corps, which was by then defunct.
January, 1860 saw the formation of the Port Elizabeth Volunteer Artillery under Captain Mathew Kemp and they soon reached a strength of about 70 all ranks, and were at gun exercise in March with two weapons horsed, a fine achievement for those days. They were evidently a busy unit and records reveal their attendance at Review days and field exercises. They fired various salutes and were even able to form a band, and in April, 1862, held a fête to raise funds. The House of Assembly voted funds in 1863 for the purchase of horses for the unit. Earlier, Kemp had asked for four 32-pounder guns and had offered to construct earth batteries for the defence of Port Elizabeth. For some reason Kemp resigned in 1863 and this seems to have paved the way for a decline in the corps and although they were able still to fire salutes and received good annual reports during the following two years, their numbers declined and from 1870 they could not raise more than 19 men. They were finally disbanded in 1876 .

1876 saw the formation of the Kaffrarian Artillery Volunteers, the Grahamstown Volunteer Horse Artillery, the Fort Beaufort Artillery and the Queenstown Volunteer Artillery Company.

Seventeen men were enrolled in the Kaffrarian Artillery Volunteers on 1st October, 1876 and by December, 1877 their strength had risen to 3 officers, of which the Commanding Officer was a Captain F.W. Bompas, and 47 men, this enthusiastic response probably being dictated by the war on the Eastern Frontier at that time. Their headquarters were in East London and apart from a five barrelled Nordenfeldt .45 machine gun they were armed with Short Sniders and bayonets.

By June, 1879, however, the strength of this unit had reduced to 2 officers and 33 men and it disappeared shortly thereafter from records.

A more successful birth was that of the Grahamstown Volunteers Horse Artillery raised in November, 1876, and equipped with 6-pounder SML's. One gun under Lieutenant Wells was present with a gun of the Cape Town Volunteer Artillery at the Battle of Umzintzani on 2 December, 1877 during the Gaika/Galeka War. Two officers and ten other ranks served on the Northern Border during the war of 1878-1879, also with the Cape Town gunners, and they were present during the Campaign in Basutoland in 1881 after relieving the Cape Town gunners who had spent almost six months in the Transkei. 
Taking over two 7-pounders from the CTVA on 28 March, 1881 for the remaining days of the Tambookie rebellion, the Grahamstown gunners handed these in and were issued with three 9pounder RML guns for use in Basutoland. These were each drawn by four horses. Apparently they were allowed to keep these guns which were replaced by 7-pounder RBL guns in 1894 . Despite their obvious enthusiasm the unit did not last beyond 1895 by which time they were dressed and equipped as Horse gunners.

The little town of Fort Beaufort produced the Fort Beaufort Artillery but little is known of them beyond a report in December, 1877, as being commanded by Lieutenant James Tudhope and having 29 men.

Raised in 1876 the Queenstown Volunteer Artillery Company remained in service until September 30th, 1880. During this short period their strength does not seem to have exceeded 24 men, first under Captain J.E. Dell and thence under Captain George Scott who took over command on 30 march, 1878. They were originally armed with Short Sniders and two 6-pounder brass guns, but in 1878 they received two 7 pounder guns. Obviously a very keen group of men they could not, in November, 1877, wait any longer for their Government issue of gunpowder and instead paid two shillings and sixpence per pound locally to enable them to practice on their guns.

In 1877 the King William's Town Volunteer Artillery appeared on the scene when the unit was formed on 5th June under Captain T.H. Giddy, with Surgeon Piers and Lieutenants Nitch and Dyer. By August their strength was 41 , all without arms. By July of the following year there were 64 members and they had been issued with Short Sniders and bayonets and one 7-pounder gun. The gun was unfortunately withdrawn a month after issue for the service on the Northern Border with another unit, but was returned in January, 1879. It is doubtful whether the unit ever had a uniform for the Volunteer Return of September, 1878 states that they had none.

The next unit to emerge was the Cape garrison Artillery and Engineer Volunteer Corps to gibe it its full title, but sometimes called the Cape Town Volunteer Engineers. Formed in 1891 this unit consisted of 4 companies of Artillery and one of Engineers and they had in fact absorbed an earlier unit called the Cape Engineer Volunteers, raised in 1859 as the Cape Volunteer Sappers and Miners, but disbanded in 1867 and re-raised under a Captain J. Tennant in 1879

The Cape Garrison Artillery, the title by which it was known from 1897, in which year it took over responsibility for the coastal ordnance previously manned by the present Cape Field Artillery, was always closely associated with the Royal Garrison Artillery who for many years found drill instructions for the unit. Mobilised in October, 1899, for the S.A. War it was demobilised in June, 1902, after spending much time on garrison duty. During the $1914 / 18$ War the CGA manned the Cape defences although as with other local units many men proceeded overseas and served either in the S.A. Field Artillery in East Africa or the Heavy Batteries in France.

In June, 1934 the unit became part of the Cape Artillery Brigade as 1st and 2nd Heavy Batteries and in the 1950's were absorbed into the S.A. Marine Corps.

Moving to the Northern Cape, the Diamond Fields Artillery was raised as the Kimberley Light Horse Artillery Troop on 19th August 1876. It seems that in October of that year a battery by name Griqualand West Volunteer Artillery and commanded by Captain R.E. Wallace with Lieutenant Geo. Richards was formed, but the fate of this unit after acceptance of service in December, 1876 is not clear. Possibly the two units mentioned above amalgamated to become what was the Artillery Battery of the Dutoitspan Hussars immediately prior to the latter being replaced in December, 1877 by the Diamond Fields Horse - described as an Irregular unit when it became known as the Artillery Troop of the D.F.H.

At the outbreak of the Griqualand West Rebellion in May, 1878, the D.F.H. had as yet not received guns and Captain Maxwell and Lieutenant Parkins went to King William's Town to fetch ordnance, arriving back on 29 May, in time for them to be in action at Koegas against the rebels, who were repulsed with heavy loss.

The Diamond Fields Horse was accepted for service in terms of the Volunteer Act No. 10 of 1882 , on 13 th July, 1887 , and was the "continuation" of the irregular corps. The Artillery troop with its "three field guns fully horsed and equipped" were also accepted for service and by January, 1896 they had four 7-pounder guns and 
38 horses with a strength of 59 personnel and a drill instructor who had been a Sergeant in the Royal Horse Artillery.

Soon after this the Griqualand West Brigade was formed and the Artillery Troop became, as from 1st January, 1897 an independent unit known as the Diamond Fields Artillery, a title subsequently changed by Government Notice 173 of 4 th February, 1905 to that of Diamond Fields Field Artillery.

The unit served in the Bechuanaland Rebellion of 1897 and in the Anglo- Boer War of 1899-1902, giving a good account of itself during the siege of Kimberley when it was armed with six new 2.5 inch 7-pounder screw guns on special colonial carriages, acquired immediately prior to the outbreak of the war.

Due to the decreased interest in volunteer service and without a full time instructor of Commissioned rank, the Comdt. General Cape Colonial Forces adopted a recommendation to transfer the Battery to the Kimberley Regiment and it remained there as the Field Battery of the Kimberley Regiment from April, 1907 until it was finally disbanded in June, 1908.

Of all the above units only Cape Field Artillery has survived the march of time although an antiaircraft unit has in recent years revived the name of the Cape Garrison Artillery.

There is one unit that may be able to claim true seniority over all others in the Permanent Force and to trace its beginnings to 1874 and that is 4 Field Regiment SAA.

Raised in 1874 by Lieutenant Robinson, late RA, as the Artillery Troop of the Frontier Armed and
Mounted Police with a strength of 50 , it was equipped with one 9-pounder and two 7pounder RML guns, drawn by teams of four and six respectively driven in hand from the limber. At first horses and later mules were used. The Troop became the Cape Mounted Rifles Artillery Troop in 1878 and served the above guns and a 12-pounder and $5 \frac{1}{2}$ inch mortar at Morosi's Mountain, where Sergeant Scott of the Troop won the V.C.

On 29th July, 1880, the Troop was renamed Cape Field Artillery under Act No. 15 of 1880 under Major Giles, RA, and it served throughout the Basutoland Rebellion of 1880-81 when they were equipped with 6.3 inch RML howitzers and three more 7-pounder RML's. The unit which merged with the CMR in 1884 , this time as horse artillery, is frequently confused with the present Cape Field Artillery, with which it has no connection.

During the S.A. War the Troop has six 2.5 inch RML screw guns, two naval 12-pounders and a Hotchkiss 13-pounder QF. In 1907 they were issued with 15-pounder $\mathrm{BL}$ guns. A detachment of the Troop saw service during the Zulu Rebellion in Natal in 1906.

When the Union Defence Force was formed in 1913 they became 1st Battery SAMR and were issued with 13-pounder guns. The following year the personnel were temporarily divided between 2nd and 3rd Batteries and the Transvaal Horse Artillery took the place of 1 st Battery, which in 1915 resumed its number.

By 1935 the title was 1st Field Battery, S.A. Artillery, changed in 1940 to 10th Field Battery, 4th Field Brigade and during the Italian Campaign of $1944 / 5$ it became 4/22nd Field Regiment, S.A.A.

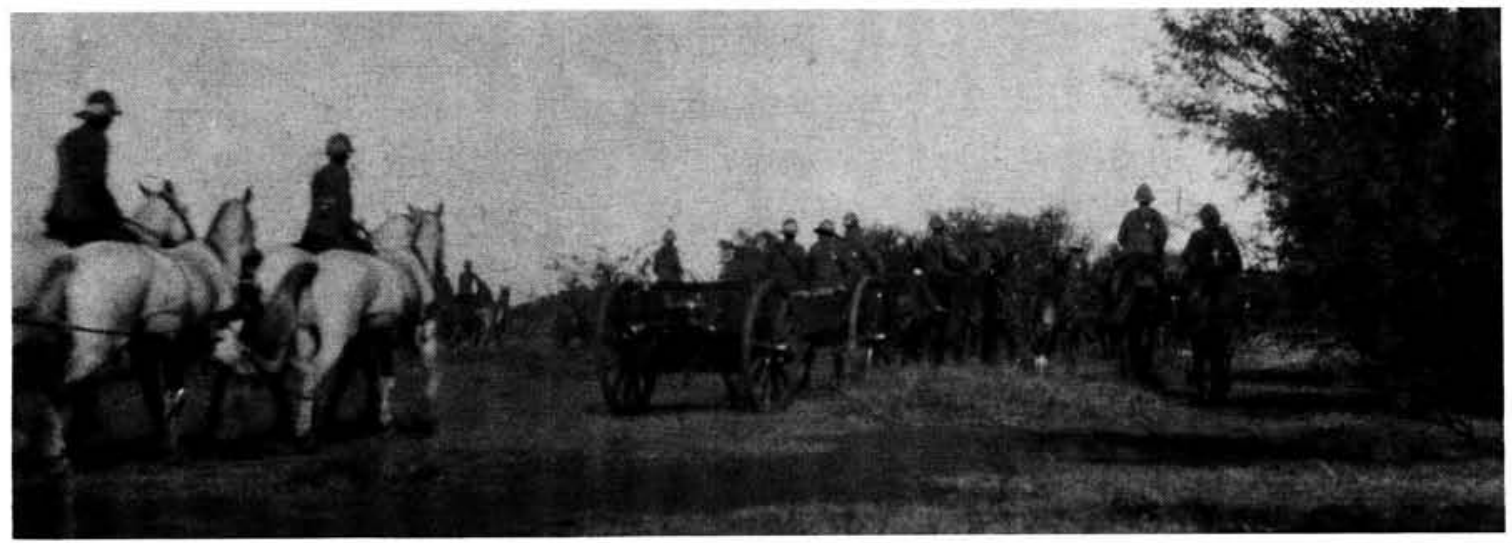

Transvaal Horse Artillery. 
After the war the unit became 4 Field Training Regiment SAA, later changed to 4 Field Regiment.

\section{Enthusiasm for the Guns was not only confined} to the Cape.

April, 1855 had witnessed the emergence for a short time of the Artillery Company of the Durban Volunteer Guard equipped with a field piece the cost of which was raised by public subscription.

In September, 1862 the Company was reformed as the Artillery Company of the Durban Rifle Guard under Captain A.W. Evans and was equipped with two 7-pounder mountain guns, but in 1870 it became a seperate unit under Captain Harry Escombe known as the Durban Volunteer Artillery, finally becoming Natal Field Artillery in April, 1892.

The Battery went to Zululand when Shepstone crowned Cetewayo and fired a thundering salute of 17 guns on 1st September, 1873, when the Coronation took place.

After the disaster of Isandhlwana in January, 1879 , a parade of troops was held in Durban to restore confidence! Two days later, the volunteer gunners took up position on the south bank of the Umgeni River to meet a possible attack by the Zulus.

The unit took part in the funeral procession of the Prince Imperial in June, 1879 from the Roman Catholic Cathedral to the Point, Durban.

Salute were also fired on other ceremonial occasions when the Railway was opened as far as Charlestown on 4th April, 1891, and when President Paul Kruger visited Natal a salute was fired as the President crossed the border. After the salute, the Artillery Battery was rushed by train to Ladysmith to fire another salute on the arrival of the distinguished visitor, and similarly at Pietermaritzburg and Durban. It is recorded that the President was surprised and impressed at the "large number of batteries of Artillery Natal possessed".

Mobilised on 30th September, 1899, the Battery was sent to Ladysmith with its six 9-pounder guns but were so hopelessly outranged and outclassed by the Transvaal Staats Artillerie that the Natal gunners were sent out of Ladysmith before the siege and took little further part in the campaign. To quote from Sir Arthur Conan Doyle's "History of the War in South Africa",
"... but the busy, smoky little guns were soon to meet their master. Away upon the distant hillside, a long thousand yards beyond their furthest range, there was a sudden bright flash. No smoke, only the throb of flame and then the long sibilant scream of the shell and the thud as it buried itself in the ground under a limber ... Such judgement of range would have delighted the most martinet of instructors at Okehampton. Bang came another and another and another, right into the heart of the Battery. The six little guns lay back at their extremest angle and all barked together in impotent fury. Another round pitched over them and the Battery OC lowered his field glasses in despair as he saw his own shells bursting far upon the hillside ... French soon came to the conclusion that, if those fifteen pounders required target practice, they should find some mark other than the Natal Field Artillery".

Together with the Dublin Fusiliers and the Durban Light Infantry, the Battery was the only protection for Natal at Colenso and Estcourt, where it was frequently in action. In September, 1901, having been re-equipped with 15-pounder BL guns, the Unit was again mobilised and sent to meet a threatened invasion in North Eastern Natal. After the Anglo-Boer War, two further batteries were raised in Durban and formed the First Brigade, Natal Field Artillery.

All Batteries saw service during the Natal Native Rebellion of 1906-7. In 1913, when the Union Defence Act came into force, the Durban Batteries ( $A$ \& B Batteries) became the Durban garrison Artillery, while the Pietermaritzburg (C) Battery became the Seventh Citizen Battery (NFA).

The NFA also saw active service during the offensive against the German forces in South West Africa from 1914 until 1915 where it was equipped with 13-pounder QF guns.

The only other Gunner unit to be formed in Natal was the Maritzburg Artillery - also known as the Natal Volunteer Hotchkiss Company - with one officer, 25 men and two 3-pounder Hotchkiss guns, which was raised in September, 1899 under Captain Walker. They served throughout the Siege of Ladysmith and had two men killed and five men wounded on Wagon Hill. The unit was disbanded in 1900 .

In the Orange Free State and the Transvaal Republic, artillery units were nearly all on permanent establishment as opposed to the voluntary 
gunners of the Cape and Natal - with the exception of the CMR Artillery Troop - and thus we find the well known Staats Artillerie van de O.V.S. which was in existence from 1857 to 1900 , and the Staats Artillerie van de Z.A.R. raised as the Battery Dingaan in 1874 and lasting until 1901 when, without guns they were re-organised as a mounted corps and fought during the Anglo Boer War until the cessation of hostilities. command in 1880 with one officer, 55 other ranks and 300 reservists under him. He had 12 modern Armstrong guns, four of which were horsed and was responsible for policing the borders. Relieved of this duty sixteen years later, the Free State gunners were re-organised and provided with 14 new $7.5 \mathrm{~cm}$. Krupp guns. With these and a strength of five officers and 159 other ranks, increased to 400 at the outbreak of

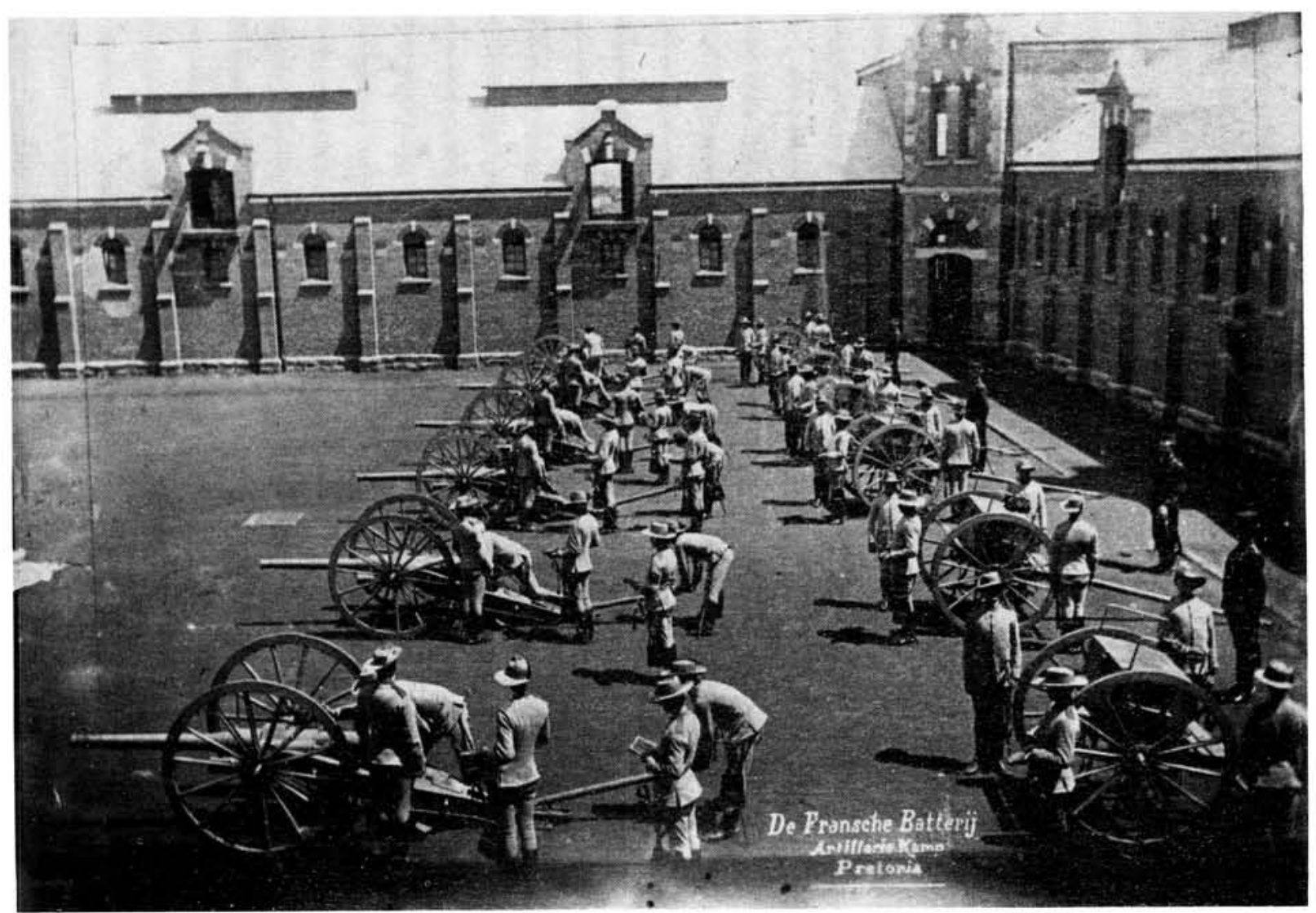

ZAR Staatsartillerie.

The Staats Artillerie van de O.V.S. had a shadowy existence from 1857 to 1864 although it took part in the 1858 Basuto War with two of the 12 field pieces purchased for it by the OVS Government. In 1864, Captain Goodman, a former Royal Artillery officer, was made Commandant with a staff of seven all ranks and during the 1865-1869 Basuto wars the strength was increased and five guns, including a 12-pounder RBL Armstrong and a 6-pounder Whitworth, were in the field, all drawn by horses. Captain van Rensburg, the Adjutant, was seconded to the Transvaal Artillery in 1882. The strength of the unit was purposely kept low, for the annual available expenditure was only £2000, but a decision must have been made to enlarge the unit for a German Army Officer, Major Albrecht, took war, the Staats Artillerie fought and gave good service until the beginning of the guerrilla war. Albrecht was captured at Paardeberg.

Battery Dingaan was first armed with four Krupp mountain guns and two mitrailleuses. In 1881, after the British occupation from 1877 to that date the Staats Artillerie van de ZAR was reformed under a Captain Riedl and by 1882 it had 30 gunners and 30 policemen. It served in five small Native wars from 1882 to 1894 when the strength was 124 other ranks under Commandant J. Wolmarans and five other officers.

In the Malaboch campaign the guns were described as being very poor for they were still the 


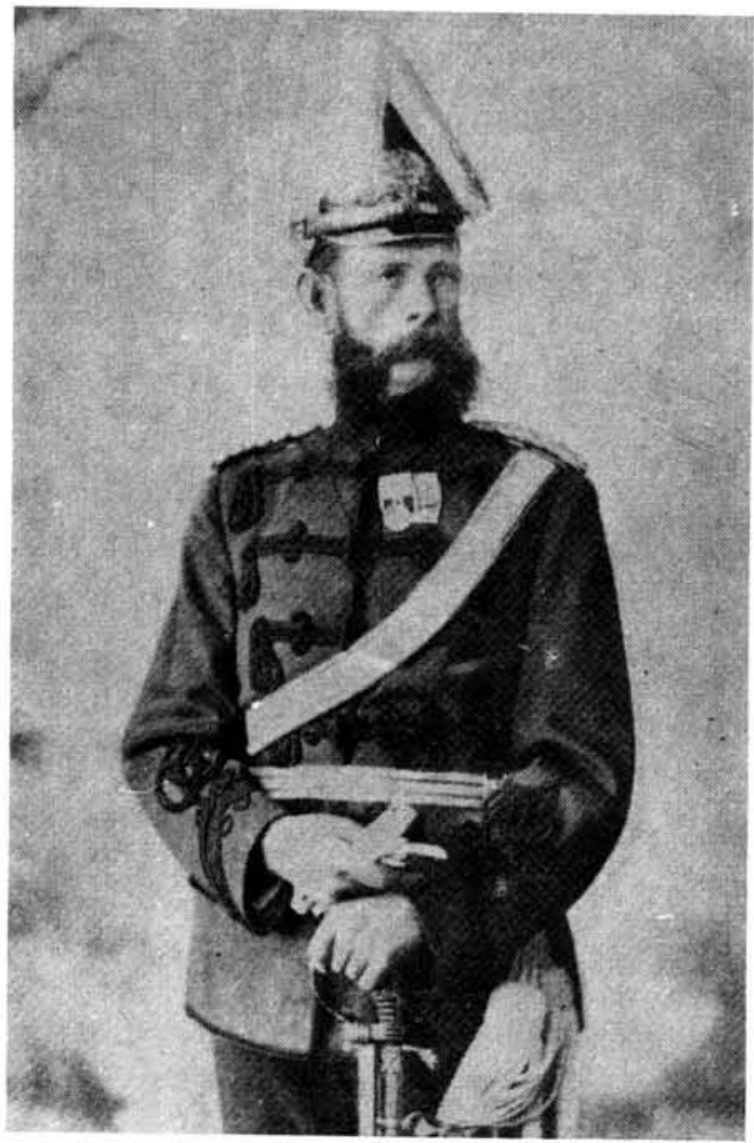

Maj R. Albrecht: OFS Staatsartillerie.

original Krupp mountain guns and in 1896 during the Jameson Raid the same ordnance only was available to $\mathrm{Cmdt}$. Trichardt and his 70 men. The intrusion by Jameson alarmed the government for immediately afterwards the establishment was increased to 23 officers and 295 other ranks, and the unit was provided with Field Telegraph and Medical sections.

The armament in 1899 was four 6-inch Creusot ox-drawn, and four 4.7 inch Krupp howitzers, eight 2.95 inch Krupp QF field guns, two Maxim Nordenfeldt and 22 one-pounder Maxims (Pompoms) all horsed. Their strength at the start of the war was 400 with a further 400 reserves. They were organised as three batteries and their reputation was very good, their handling of the heavy Creusot guns in the field being especially commendable.

One of the best known of their officers was Major J.F. Wolmarans who fought throughout the War until captured in January, 1902. He subsequently commanded the 4th Permanent Battery, U.D.F., in German South West Africa in 1915, where he gained the DSO.
Another gunner unit, the Pretoria Artillery was raised in 1874 under Commandant J.R. Lys with a strength of 25 and in 1877 another group of Pretoria volunteers formed the Transvaal Artillery under a Captain Knox, RA. The NCO's were all provided by the Royal Artillery and the total strength was 53. During the Sekukuni Campaign of 1879 it consisted of a mixed six gun Battery one 3-pounder, one 6-pounder, two 7-pounder mountain guns, all pack guns on horses, and two $4 \mathrm{~cm}$ Krupp BL guns drawn by oxen. During the siege of Pretoria in 1881, the unit consisted of 12 men with one Krupp and a Whithworth, probably a 6-pounder.

The only volunteer unit raised in the Transvaal was the Transvaal Horse Artillery which came into being as the Lys Volunteer Corps in March, 1904, under Major Godfray Lys. They were redesignated Transvaal Horse Artillery Volunteers in September of that year, dropping the last word from their title in 1908.

This unit has, in common with CFA and NFA, always enjoyed a high reputation and has attracted from the beginning a fine class of recruit, including the volunteer officers and NCO's of today.

Headquarters in Johannesburg, it has always been close to the centre of military activity in the UDF (later SADF) and when the Permanent Force was about to be formed it was at the THA Headquarters that a School of Gunnery was formed in September, 1912.

The reason partly was that an RA officer has always been allotted to the THA for instructional purposes in addition to administrative duties as Adjutant and in 1912 Captain Hay, RHA, the then incumbent of the post, was given the task of training officers and NCO's for the Permanent Batteries about to be established. The guns, equipment and quarters of the THA, together with some of the barracks, rooms and stables in the Police Camp immediately to the South of the headquarters were used for instructional purposes. Several THA officers and men assisted at the field firing which concluded each of the two six month courses held.

Included in the establishment of the Permanent Force vide Act No. 13 of 1912 were five batteries of field artillery to be attached to the five regiments of the S.A. Mounted Rifles and the artillery of the then UDF was to include CFA, NFA and 


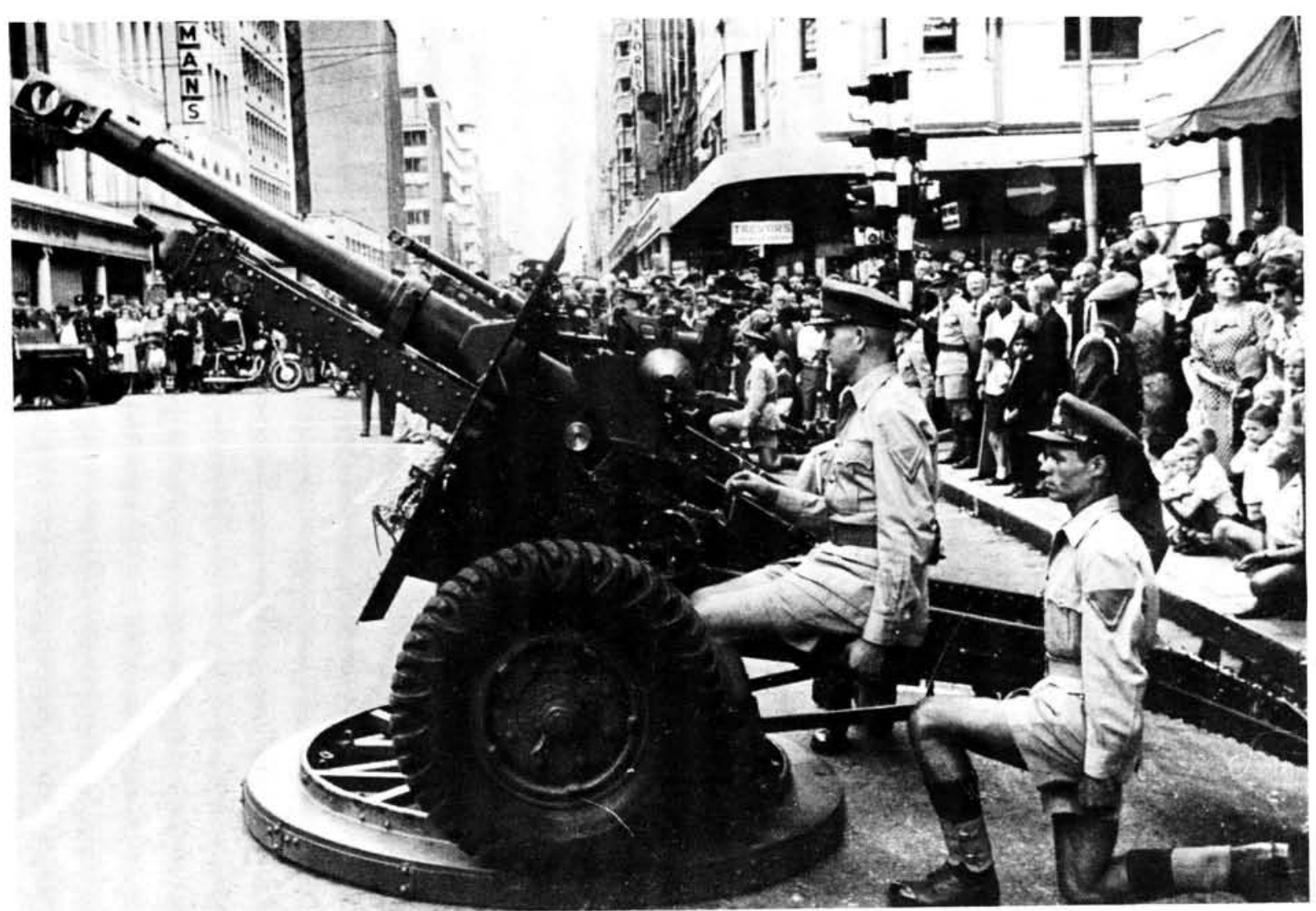

Transvaal Horse Artillery.

THA - all that remained of the many volunteer gunner units - as 6th, 7th and 8th Citizen Batteries respectively. The 3 rd and 5 th Batteries were not formed and when war broke out in 1914, 1st Battery personnel were used to fill the 2nd and 4 th. Three other batteries - 9th, 10th and 12th were raised for the campaign in German South West Africa, all men in the S.A. Police who had artillery training being allowed to volunteer into the S.A. Artillery. In addition to the field batteries, a Brigade of Heavy Artillery was formed at Cape Town which rose to a strength of 60 officers and 1000 other ranks before the close of the S.W.A. campaign. Men were drawn from the Royal Marines, Royal Garrison Artillery, the Cape Garrison and Durban Garrison Artillery and three Brigades were eventually formed. Later, from these Brigades and other volunteers five Heavy Batteries, 1st to 5 th Siege Batteries were formed for service in France. Only men of fine physique and of a standard height of 5 feet 8 inches were accepted.

1st Battery represented the Western Cape, 2nd the Eastern Cape, 3rd the Transvaal, 4th Kimberley and the Diamond Fields and the 5th, Natal. Before they appeared on the fighting front the British War Office decided that they should be rated as siege artillery, armed with 6-inch howitz- ers and affiliated to the Royal Garrison Artillery. This involved each battery receiving an RGA number and so they became 71 st and 75th Siege Batteries RGA.

In April, 1916 a sixth battery, the 125th was formed and early in 1918 a seventh battery, the 542nd and an eighth, the 496th, were created but on arrival in France their guns and personnel were distributed between 75th and 125th Batteries, and the 72nd and 74th Batteries respectively. A ninth battery, the 552nd armed with 8inch guns was formed in the autumn of 1918 but the war ended before it could be brought into action.

To fill the gap caused by diluting the 1st Battery SAMR into 2 nd and 4 th, the THA took the place temporarily of the 1st Permanent Battery with the title "THA Battery SAMR" and fought in S.W.A. showing great determination at the action at Sandfontein in September 1914 when one section had 28 casualties out of a strength of 40 all ranks having fought the German guns at odds of six to one until its ammunition was exhausted.

Immediately prior to the entry of S.A. Forces into G.S.W.A. the Cape Field Artillery, the only gunner unit used by General Louis Botha in 1914 to 
help subdue the rebels under De Wet, found itself at Upington as part of the Southern Force under General van Deventer when German troops under Maritz with artillery support attacked the town after calling for its surrender. After three days on the alert, 24 January, 1915 saw many gunners receive their baptism of fire when Upington awoke at 5 a.m. to the sound of artillery, pom-pom and machine gun fire as Maritz attacked. In the ensuing battle the 15-pounders of the CFA fired more than 360 rounds with nothing more than few marks left by pom-pom shell splinters on ' $A$ ' gun - and on the buttocks of one unfortunate gunner - when in the early afternoon the gun was detached to support the pursuit of the enemy forces who by then had had enough after losing 60 killed and 136 captured.

Signing himself "one who was there" in a letter to the Sunday Times, a reader said "The town was saved by the Cape Field Artillery, assisted mainly by the 18th MR and by the 8th MR ... the CFA covered themselves with glory, and deserved every praise, as they saved Upington and acted as seasoned soldiers".

It has to date been the only artillery duel to have taken place against guns of a foreign power attacking on South African soil.

About the middle of 1915 when the Campaign in South West Africa was almost ended, the South African Government began recruiting volunteers for five batteries of field artillery for service overseas. A camp for the new Brigade was established in what had been the Imperial Cantonments at Wynberg, and an artillery training depot was established there. The first Brigade Order was issued on 24th August, 1915. Equipment was at first in short supply but as more arrived so more space was needed, especially for stabling. and the Brigade moved on 6 December, 1915 to Young's Field. Training continued there, with the first live shell practice taking place at Sir Lowry's Pass at the very end of December, 1915.

Four months and two weeks saw the recruiting and training of the Brigade completed and shortly after a ceremonial parade in "field service marching order" on 5 January, 1916, at Young's Field it left for East Africa to take part in the campaign against the German forces under Colonel Paul von Lettow-Vorbeck, departing from Cape Town in the S.S. Egbert and HMS Armadale Castle. Men from the Cape had been posted to 1st Battery; from Natal to the 4 th; from the Transvaal to the 2nd and 5th and men from the Orange Free State and extra men from other provinces to the $3 r d$.

Although called "Field" the Brigade was organised and equipped as Horse Artillery for the gunners were all mounted, not seated on the limbers as in field artillery. The guns were drawn by teams of six mules with Coloured and African drivers riding postillion.

The Batteries arrived at Mombasa in mid-February and in the six months ending August, 1916, the S.A.F.A. Batteries took part in the campaign under General Smuts which cleared the entire area north of the Central Railway. Although the well-led German forces had not been destroyed, they had lost control of the country and only guerrilla warfare lay ahead, so most of the S.A.F.A. Batteries were withdrawn, leaving for South Africa in April, 1917.

It was a campaign fought in "miserable and arduous conditions ... in the rainy season ... the roads were impassable, the malaria mosquito and the tsetse fly were rampant, and food for both men and beasts was difficult to obtain".

There was a continual shortage of ammunition as well as other supplies, and although battle casualties had been light, the casualties of men and animals from disease and under-nourishment had been very heavy indeed and had often hampered operations, but the guns had continued to work in close support of the infantry and were able to prevent loss to our men by effective fire on many occasions.

Early in the campaign an officer won the M.C. and a gunner the D.C.M. in an attack on the German positions in which one of the heavy guns taken from the German cruiser Konigsberg was destroyed. A month later in General van Deventer's march on Kondoa-Irangi the enemy was twice forced to surrender or withdraw by heavy accurate artillery fire.

The 3rd Battery was the first motorised S.A. Artillery unit when for lack of horses it was equipped with mechanised transport late in 1916. "It must have been the most motley unit that ever moved into battle", says an historian, of the collection of lorries in various stages of repair.

The first half of 1917 was spent by the S.A.F.A. on leave and re-organisation and re-inforcement in Potchefstroom, before leaving for Palestine without their Coloured drivers - where the bri- 
gade was attached to the 75th Division. After training in Egypt and conversion to Field Artillery armed with 18-pounder guns instead of the 13pounder they had brought with them, the Brigade took part in the Third Battle of Gaza, advanced to the Judaean hills, where it spent the winter of 1917, and then moved with the division to the coast for the final breakthrough under General Allenby that ended the campaign in the Plains of Sharon in October, 1918.

In the Gaza Battle the Brigade distinguished itself. Working in close support in fluid warfare ' $A$ ' Battery twice found itself in front of its own infantry at nightfall. Fighting under rifle fire at ranges down to 1200 yards they helped repel counterattacks by the Turks. The gunners were thanked by the British General for their "magnificent support", and the commander of 'A' Battery was awarded an immediate D.S.O.

In dealing with the later action at El Maghar the British Official History refers to the fine support given by the S.A.F.A. Brigade to the Somerset Light Infantry and the Infantry Commander himself in a Routine Order dated 14 November, 1917, said:

"The Infantry Commander conveys to all ranks of the S.A. Field Artillery his appreciation of the good work done today. He does not think the shooting could be improved upon ..."

The capture of the commanding position of Nebi Samwill (Mizpah of the old Testament) about five miles north-west of Jerusalem which was known as the "Key to Jerusalem" by the 75th Division resulted in the Division (and the S.A.F.A.) being granted as its distinctive sign a key which was stencilled on the shields of its guns and in suitable places on other equipment.

Although the war was over in mid-September, 1918, the brigade went into Army Reserve finally moving back to Ismalia, Egypt in April, 1919, and thence to South Africa and demobilisation.

The S.A. Heavy Artillery batteries in France matched the quality of service given hy their comrades of the field guns in East Africa and Palestine. They served first in France as separate batteries, but in April, 1916 they were joined by 125 Battery and at the beginning of 1918 the six batteries became two South African Heavy Brigades. The list of their actions reads like a roll of the historic battles of France and Flanders Ypres, Hindenberg Line, Somme, Beumont
Hamel, Cambrai. They supported not only British units, but Canadian and Belgian, and sometimes their own S.A. Infantry Brigade.

Losses were heavy. At third Ypres one battery in the salient was reduced from four guns to one; and to 70 men. Another had nine guns knocked out in one four-month spell. The spirit of the Brigade was epitomised at Arras, where 74 Battery was the furthest forward siege battery on the British front; and in 1918 when the battery supporting 44 Infantry Brigade was ordered to destroy its guns because the attacking Germans were almost on the position, the Battery Commander turned out his men with every rifle they could lay hands on and so prevented the Germans from reaching the guns.

In 1922 the S.A. Defence Force Amendment Act was promulgated and it provided for the reconstitution of the Permanent Force and the disbandment of the SAMR.

The S.A. Permanent Force was eventually reconstituted on 1st February, 1923 and included the establishment of the South African Field Artillery and the South African Permanent Garrison Artillery on the same date, although it was apparently not until March, 1923 that the newly constituted units of the SAFA and the SAPGA were officially gazetted. The Batteries of the SAMR became the 1st Brigade SAFA with personnel and organisation unchanged. The Brigade Commander held the rank of Major and the Battery Commanders were Captains. It is interesting to note that the Brigade Commander was ex-ZAR Staatsartillerie and the BC's one exCMR, one ex-Staatsartillerie and one ex-THA.

The headquarters of the Brigade was moved from Potchefstroom to Roberts Heights (now Voortrekkerhoogte) and it is at this time that the Gunner Officer's Mess at Potchefstroom was handed over to Witrand Mental Hospital.

Each year during the 1920's and early 1930's the Brigade trekked to Potchefstroom with their guns and horses for manoeuvres and live shell practice and thereafter the various ACF (now Citizen Force) units used to do their annual training using the guns and horses of the S.A.F.A. Many hard-bitten old NCO's and gunners used practically to weep seeing their favourite horses at the tender mercies of amateur riders and drivers. CFA during these years used the artillery range at Klaasjagersberg in the Southern Cape Peninsula for annual camp and live shell training. 


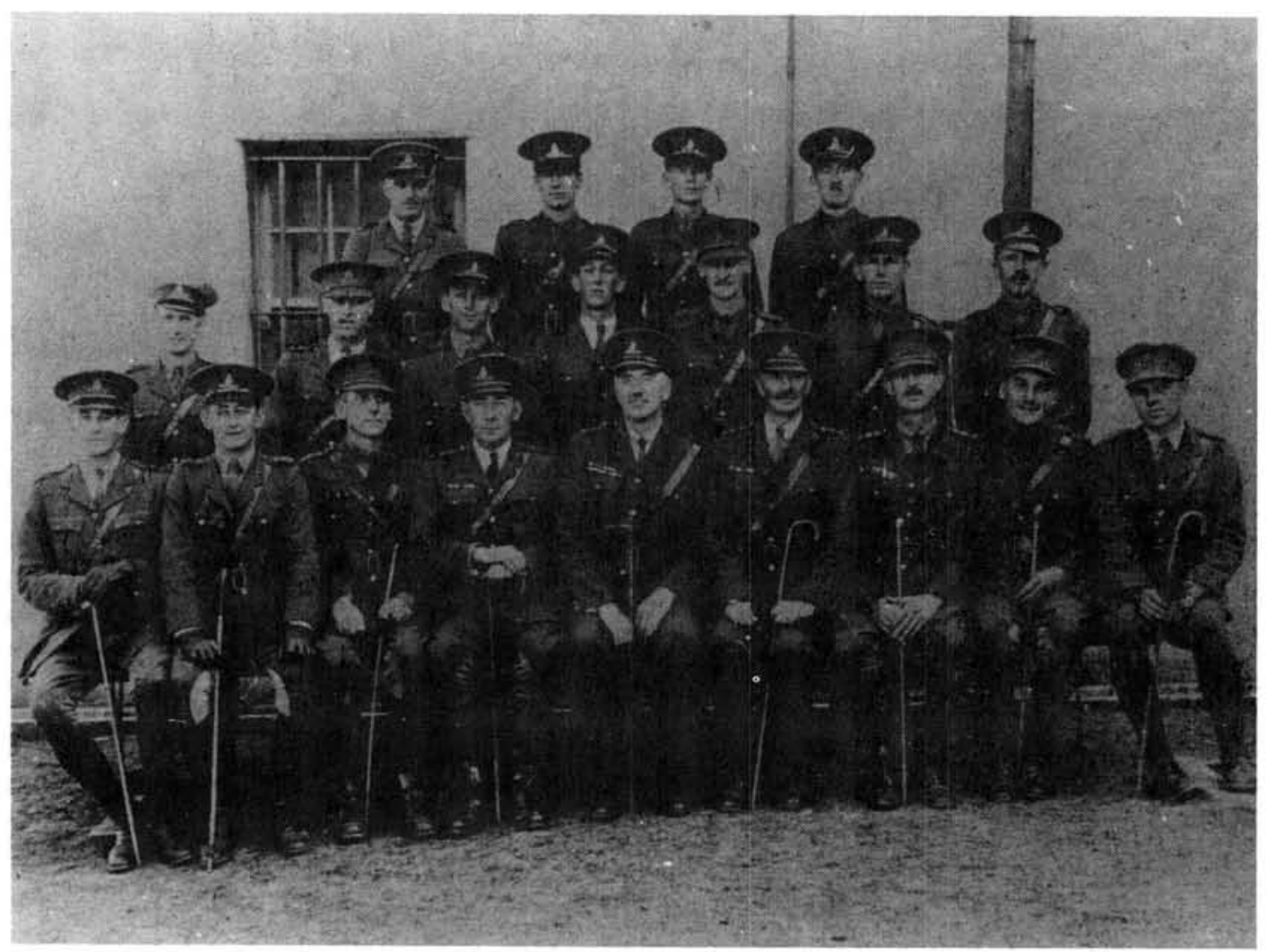

Officers: SA Garrison Artillery.

In 1923 the S.A.F.A. returned their 13-pounders to store and were issued with 4.5 inch Howitzers for 1st Battery and 18-pouners for 2nd and 3rd Batteries. The howitzers were the guns used by the original S.A.F.A. in Palestine in World War I and still had the "Key to Jerusalem" painted on their shields. These were carefully and faithfully repainted each time the guns were repainted, right up till 1940. The S.A.F.A. Brigade survived until 1926 when the 3 Batteries became independent units.

Until this time the only Citizen Force units had been the CFA, NFA and THA but in 1926 two new Citizen Batteries, the 4th and 5th SAFA were formed at Bloemfontein and Bethlehem becoming in 1932 the 1st and 2nd OVS Veld Artillerie. These two units were each later diluted by a Permanent Force Cadre from 3 Field Battery and were headquartered at Bloemfontein and Bethlehem. Today they are known as 6th Field Regiment after having at one time existed in the 1950's and 60's again as separate units known as Vrystaatse Staatsartillerie and 6 Field Regiment.

A Corps of Artillery as we know it today was formed on the 1st September, 1934, and it in- cluded all independent units of both the Permanent and Active Citizen Force, each of which retained their number and name. They were gazetted on 14th December as units of the South African Artillery, the word "Field" being finally dropped from the title.

It is interesting to recall that the Royal Artillery were responsible for our Coast Defences until 1921 although in practice a large proportion of RA personnel were withdrawn and the Cape Garrison Artillery manned the Table Bay and Simonstown defences whilst the Durban Garrison Artillery manned the guns on the Bluff.

On 1st December, 1921, the Imperial South African Military Command in the Cape Peninsula was transferred to the Union of South Africa and the SAPGA took over the armament at Cape Town and Simonstown, the Durban defences being closed down. The original establishment of the SAPGA included the men of the Cape Garrison Artillery and it was thus a combined Permanent and Citizen Force unit divided into a Headquarters and two Companies, No. 1 being responsible for Table Bay and No. 2 for Simonstown. These were later expanded to four companies. 
The garrison gunners, however, underwent reorganisation in 1934 when on 1st June, the Coast Artillery Brigade was formed and under the new organisation the four coast companies were merged into the 1st and 2nd Heavy Batteries with mixed PF and ACF personnel, the Battery Commanders, for instance being Permanent Focre and the Battery Captains being CGA personnel. The CAB Headquarter sections composed entirely of CGA (or ACF) details were also formed at this time and were designated "Engineer" and "Signalling" sections respectively. Headquarters of 1st Battery was at Cape Town and No. 2 at Simonstown.

Also part of the CAB (Coast Artillery Brigade) were Cape Field Artillery (Prince Alfred's Own) as they were by then known - with headquarters at the Castle and equipped with 18-pounder field guns, No. 1 Armoured Train - headquarters at Fort Knokke, 1st Medium Battery with 60pounder guns and 2nd Medium Battery with 6inch 26 cwt. Howitzers. Both medium Batteries had been established with effect from 1st June, 1934, and were composed of one third Permanent Force and two thirds students of the University of Cape Town.

Further changes took place during 1936 when CFA Reserve Battery formed the previous year came under command from 1st August, 1935, the Battery Commander being Captain C.R. (Ginty) Divine. Also, the Heavy Batteries were seemingly split for the Historical Return for the year shows 1st and 2nd Heavy Battery CGA and 1st and 2nd Heavy Batteries PF, although by the following year these are shown as 1st and 2nd Heavy Batteries SAA. The CGA and SAA Batteries had different establishment tables.

Also in 1936 2nd Medium Battery was re-designated 3rd Heavy Battery CAB from 8th July and allotted 6-inch MK XIX guns and it is interesting to note that while they carried out "practice seawards at Port Natal from the Bluff on 5.5.38. firing 50 rounds HE fuze 106, Capped, Charge Full", they were about the same time issued with "four R.D.6" Caterpillar tractors, in addition to Ford V8 delivery vans and wireless vans.

The 3rd Battery were split between the Port Elizabeth and East London defences at the outbreak of war in 1939 by which time the CAB also included 1st Anti-Aircraft Battery (3-inch $20 \mathrm{cwt}$ guns). Early in 1940 it consisted of 1st Heavy Battery (Cape Town), 2nd Heavy Battery (Simonstown) 5th Heavy Battery (Robben Is- land), 8th Heavy Battery (Saldanha Bay) and 1st Anti-Aircraft Training Brigade at the Rosebank Showgrounds.

On 8th February, 1940 the CAB HQ was abolished and 1st, 2nd and 8th Heavy Batteries came under Command of a new headquarters, and in July, 1951 the CGA and all other Coast Garrison Force units were transferred to the S.A. Corps of Marines.

It is very interesting to note the order of precedence of seniority, laid down by Force Order No. 104 in 1935 which read:

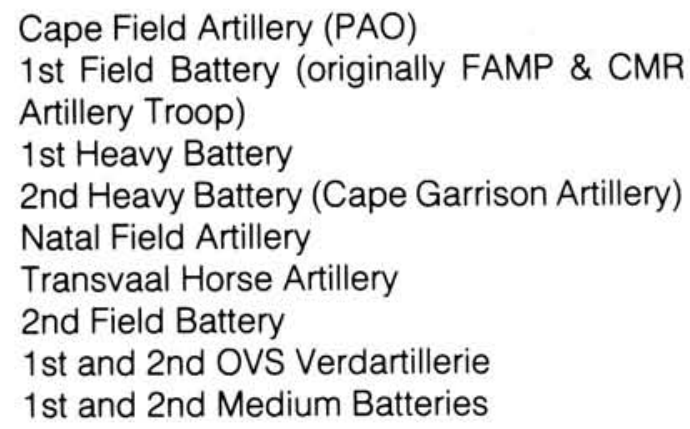

After the S.A.F.A. had departed in January, 1916 for East Africa the South African Field Artillery Depot whose purpose was to train more recruits for the Brigade was established at Potchefstroom and it was here that for some years Artillery training was conducted.

However, on 7th September, 1934 the Artillery Training Depot was established at Roberts Heights and it was composed of the two S.A.F.A. Batteries stationed there. The Depot supervised the annual training of all field artillery units. 24th October, 1936 saw an alteration of name to Artillery School and at the same time the functions of the school were clearly defined as administration, instruction and experimental work.

In July, 1939, all the then existing Field Army Artillery units at Robert Heights were allocated to the Artillery School for purposes of recruiting, organisation and general administration, but when in mid-October the Artillery School was transferred to Potchefstroom provision was made for the appointment of a Deputy Director Field Army Artillery Training with the rank of Lieutenant Colonel. Due to the huge increase in artillery training as a result of the declaration of war in 1939, Potchefstroom became the Artillery Training Centre and by July, 1940 the Artillery School ceased to be a section of the A.T.C. and became a seperate unit under Defence Head- 
quarters, Pretoria. Almost a year later the School and the A.T.C. were again combined as one unit but were later separated and the School in 1946 became the School of Artillery and Armour, changing to School of Artillery from 1st February, 1964.

With the outbreak of the Second World War Gunner units were among the first to be mobilised, and new regiments were swiftly added to the cadre that had existed in peacetime.

South African troops took a prominent part in General Cunningham's advance from Kenya into the heart of Italian East Africa. In these operations the S.A. Artillery played an important role. Indeed, apart from an East African and West African Light battery and an Indian Mountain battery, the Field Brigades, 1st Field Battery (PAOCFA), 1 Anti-tank Brigade, 1 Medium Brigade, and 1 and 2 Anti-aircraft Brigades.

The artillery fired with great effect in the battle of the Juba, while Brigadier Pienaar made good use of his batteries in his successful advance from Jumbo to Jelib. At the battle of Marda Pass the commander of the Nigerian Brigade paid tribute to the shooting of 7 Field Brigade and 1 st Field Battery (PAOCFA). Under the heavy pounding from the guns the enemy retired from the pass.

After the fall of Addis Ababa, 3 Field Brigade and a section of 1 Medium Brigade were heavily shelled by guns sited in the hills above them during the attack on Kombolca Pass but in a series of duels over several days, the South African gunners mastered their opponents.

Meanwhile the gunners supporting the 11th and 12th African Divisions in the area of the lakes were nearly swamped by rain like that which their fathers had known in East Africa.

With the end of the Abyssinian campaign the 1st Division moved north to Egypt where it was joined by 2nd S.A. Division, which included 1, 2 and 4 Field Regiments, and 2 Anti-tank Regiment, the organisation into larger regiments having replaced the brigade system of 1939 . Here the field regiments were first equipped with the famous 25-pounder gun.

In the flat, dusty, stony expanse of the Western Desert these guns gained new importance, particularly as a defence against the tank. Often it was the decisive weapon in stopping the Ger- man advance, and battles developed into duels between tanks and guns and the German Air Force gave particular attention to gun positions in attempts to knock them out.

Almost from the start of the November, 1941, advance into Cyreniaca 1st Division fought off tank attacks. On 23rd November at Sidi Rezegh the Panzer divisions swept over 5th S.A. Brigade after a battle described by Col. Kribel of 15 panzer Division as "the fiercest of the entire campaign". Despite mounting casualties the gunners fought their guns until overrun by the tanks or until ammunition ran out. The British 22nd Armoured Brigade noted in its war diary: "From what could be seen from our final drive through the enemy's right flank their tank casualties were heavier than in any previous engagement. The S.A. gunners had been magnificent".

Two days later Brig. Dan Pienaar's 1st Brigade with strong artillery support fought off an attack by Italian tanks.

In January, 1942, the infantry of 2nd Division in bitter cold stormed the fortress of Bardia supported by the largest setpiece barrage undertaken by South Africans in North Africa, except Alamein. To the West the S.A. Artillery suffered heavy loss when working with the 1st Armoured Division which was broken up by the German advance.

Further severe losses were suffered in the retreat from Gazala and in Tobruk, when batteries distinguished themselves in tough and gallant stands like that of 6th Battery (NFA) at Rigel Ridge. Such were those of 2nd Battery (CFA) and D troop of 5th Battery who were right in the line of the panzer breakthrough at Tobruk. D Troop's four guns faced 45 German Tanks. Heavy machine-gunning wounded the crews who hung on, firing each gun until it was finally knocked out.

As the Germans approached Alamein along the coast the 1st S.A. Division, including CFA, reinforced by 7 Medium Regiment, Royal Artillery, blocked their path. The Germans tried to swing south and sidestep the Alamein box. What happened next is described in the war diary of the German crack 90th Light Division.

"Under the protection of the sandstorm the advance progresses very favourably at first, but is brought to a halt about $7 \mathrm{~km}$ to the east by violent artillery fire. The enemy is firing into the division 
with every gun he has. It seems impossible to break through in any direction. Units have collided unexpectedly with the strongpoint system. A panic breaks out which is stopped just in time by the action of the Divisional Commander. Supply columns and even parts of fighting units rush back under the ever-increasing enemy artillery fire. The division digs itself in".

The first dangerous German rush on Alamein had been stopped.

Throughout July, 1942, South African Gunners were fully engaged in the stubborn fighting which followed this staggering initial repulse inflicted on the enemy by the South Africans.

On the night of 23rd October, when the tide of war started to turn, South African gunners fired 62,500 rounds of ammunition in the war's biggest barrage to that time, as they supported their infantry comrades in General Montgomery's attack.

The official historian says: "Having played a worthy part in the decisive battle in the desert, the Gunners, when 1 S.A. Division was finally relieved, returned to the Union in December, 1942".

When the artillery was being formed and trained for South Africa's first armoured division, the units from 1st Division were amalgamated with those already training in the Union to bring them to full strength. The artillery regiments of 6 S.A. Armoured Division carried the titles: 1/6 Field Regiment, 4/22 Self-Propelled Regiment, 7/23 Medium Regiment, 1/12 Light Anti-Aircraft Regiment, 1/11 Anti-tank Regiment.

In the close country of Italy the artillery reverted to its normal role of support for infantry and armour. During the sweeping advance which took the division through Rome and up the Tiber Valley to the Trasimeno line at Chiusi set-piece attacks were rare, but the gunners worked closely with the leading units to give fire when called for. At other times the fortified German defence lines brought static warfare which called for heavy artillery preparation for a breakthrough, such as at Cassino where South African guns supported the final attack.

The techniques which had been developed by the Allies for swift and flexible control of large numbers of guns were practised with deadly effect. This was shown in the bitter struggles in the Italian hills north of Florence, where the South Africans were involved in some of the fiercest fighting of the war. Intelligence reported: "All prisoners of war say that never in Russia or any other field of battle have they experienced such accurate and concentrated artillery fire".

At the beginning of 1945 the division was joined by a new formation, 13 S.A. Motor Brigade, with 15 Field Regiment, in time to support the gallant attacks on Monte Sole and Caprara which broke the German line and heralded the sweep across the valley of the Po bringing German collapse as the war drew to a close.

In addition to the units with divisions in the field the South African Artillery manned defences of harbours and other installations, not only in South Africa but also in the Middle East.

Regiments come and go. Many of those mentioned no longer exist and whilst their disappearance always leaves a sense of regret it is perhaps vital to infuse new blood into any organisation. Among many units who no longer appear on the Establishment Table are 5th Field Regiment (later Regiment Algoa Baai), 1st and 5th Coast Regiments, No. 1 Armoured Train of the old Coast Artillery Brigade, and 1st, and until fairly recently, 7th Medium Regiments, S.A.H.A. The latter were the only S.A. gunner units to wear "trews".

Some gunner units originally began as infantry, such as the Pretoria Highlanders - later to become 1st Anti-Tank Regiment, and the S.A. Irish, who, after they were badly cut up at Sidi Rezegh in November, 1941, supplied the nucleus of 11 th Field Battery, 4th Field Regiment, but later became 22nd Field Regiment S.A. Irish. They combined to fight in Italy as 4/22nd Field Regiment and reverted after the war to the title of 22nd Field Regiment and later to their infantry role as S.A. Irish.

Units formed since the 1939/45 war include Regiment Universiteit Pretoria (formed in March, 1950 as the Observation and Sound Ranging Battery of 1 Locating Regiment, but changed in 1953 to a Field Battery and re-designated R.U.P. in 1960, but now known as 17 Field Regiment), the Regiment Potchefstoomse Universiteit also formed in March, 1950, Transvaalse Staatsartillerie formed early in 1954 as 9th Field Regiment (Staatsartillerie) S.A.A., and given their present title in 1960 and also Regiment Laeveld - now off 
the establishment table - Regiment Universiteit Oranje Vrystaat - now part of 6 Field Regiment.

1 and 2 Locating Regiment, and Anti-Aircraft Artillery, such as the Cape Garrison Artillery (formerly University of Cape Town Regiment and originally 4th Heavy A.A. Regiment S.A.A.) Regiment Vaalrivier, 10 Anti-Aircraft Regiment, 6 and 7 Light Anti-Aircraft Regiment and Regiment Oos Transvaal, amongst other, help to fill the current picture.

The story of guns and Gunners in South Africa would not be complete without mention of an interesting experiment initiated in September, 1941, when 23 Field Regiment was raised in Zululand. Half the personnel in the unit were Zulus. Similarly, 22 Field Regiment experimented in 1943 with Cape Coloured gun numbers, but in each case the non-whites were withdrawn before the units proceeded on active service. The precedent for the experiment had been set by the Malay Artillery of 1804 , and by the inclusion of Coloured drivers in the original S.A.F.A. Brigade.

Towards the end of the North African campaign the Cape Corps provided men to Ack-ack units as gun numbers under white Numbers Ones, as well as for the Coast Artillery. Many African gunners saw service with R.A. Field units and took part in the landings in Sicily and Italy. 85th Mountain Regiment, R.A. had 500 Basutos as mule drivers. However, the African gunners were drawn from the African Pioneer Corps, raised in the original three High Commission territories.

Mention should also be made of Kitchener's Horse, which came into being in 1900, "E" Squadron of which was supplied entirely by the Cape Garrison Artillery, and of the S.A. Marine Corps - formed in 1951 as a resuscitation of the S.A. Coast Artillery; 6th Light Battery recruited in the Transkei and merged with the Cape Field Artillery in 1940, 1st Field Battery CFA, who fought as an independent unit in Abyssinia and were afterwards amalgamated with 7th Field Brigade to form the 7th Field Regiment - the list seems almost endless. Amongst those who should not be forgotten are the women of the Women's Auxiliary Army Services, many of whom during the last war were attached to Coast Artillery units as signallers, radar operators and plotters, and who were proud to wear Gunner grenades on their uniforms.

Gunner tradition in South African at one time relied heavily on that of the Royal Artillery. There is no doubt that the latter have had an inestima- ble influence on the S.A.A., but South African Gunners can be more proud of the wonderful tradition of service to the guns which they themselves have helped to build and which has proved that Gunners in this country have a reputation second to none.

Incidents that come to mind as this is written include the stand of 5th Battery (NFA) at King's Cross outside Tobruk when in the face of a fierce German onslaught, the guns were served until, one by one, they had all been silenced; 6th Battery (also NFA), covering the withdrawal of the Guard's Brigade from Rigel Ridge, an action which the Royal Artillery Commemoration Book describes as "the most glorious action fought by the South African Artillery during this period" both battles resulting in the whole regiment being captured - the defence of Alamein when 1 Field Regiment (PAOCFA) - (less one battery also captured at Tobruk - a story in itself), under heavy Stuka attack, fired over 8000 rounds in one day, with under-strength gun detachments, ears bleeding from the continuous concussion, collapsing on the guns through sheer exhaustion but causing the German 90th Light Division to panic and halting the advance to Cairo. And let us not forget among many other examples of Gunner spirit - the THA at Sidi Rezegh, fighting in rising smoke and dust over open sights at ranges measured in only hundreds of yards when with other Artillery units, they endeavoured to stop the German Panzers who finally crushed the 5th S.A. Brigade. It is to their credit that after 3 days fighting 5 of their 24 guns were saved from the carnage of the battle. Tribute to the courage and fighting qualities of the "British Artillery" at Sidi Rezegh was paid by the Panzer Commander, Major Genral F.W. von Mellenthin in his book, "Panzer Battles".

Taking names at random from the past: Umzintzani, Wepener, Kwaggafontein, Sandfontein, Gaza, El Maghar, Palestine, Ypres, the Somme, Cambrai, the Juba, Marda Pass, Combolcia Pass, Gazala, Tobruk, Alamein, Cassino, Paliano, Monte Sole, Caprara, Stanco, Bardia, Sidi Rezegh, Rigel Ridge, Kings Cross:- whether they were small actions or big battles, the South African Artillery has rightly earned a place of honour in the South African Defence Force of today and its traditions that promise loyal and gallant service live as strongly as ever.

*Col. L.A.Crook, SM, JCD, joined the Citizen Force on 1 July, 1949 and
commanded Cape Field Artillery from 1973 to 1979. He is presently Deputy Director Artillery (Field) (CF). 